\title{
DOM, CZYLI DZIEDZICTWO OBOK MNIE - DAJMY SIEZ ZAINSPIROWAĆ NARODOWEMU INSTYTUTOWI DZIEDZICTWA
}

Recenzja książek:

Dziedzictwo obok mnie - poradnik zarzqdzania dziedzictwem w gminach, zespół redakcyjny: Aleksandra Chabiera, Anna Kozioł, Bartosz Skaldawski, Narodowy Instytut Dziedzictwa, Warszawa 2016

DoM. Dziedzictwo obok mnie - inspiracje do działań lokalnych, zespół redakcyjny: Aleksandra Chabiera, Anna Kozioł, Bartosz Skaldawski, Warszawa [2016]

Narodowy Instytut Dziedzictwa systematycznie i konsekwentnie do swojej działalności wydawniczej, animacyjnej i metodycznej włącza promocję dobrych praktyk służących ochronie dziedzictwa, które uwzględniają potencjał i udział środowiska lokalnego. Ten zwrot zbiega się z ratyfikacją w roku 2011 przez Polskę Konwencji UNESCO w sprawie ochrony niematerialnego dziedzictwa kulturowego z 2003 roku, wzmacniającą rolę depozytariuszy w procesie ochronie dziedzictwa. Naprzeciw tej idei wychodzi misja NID, którą jest między innymi „kształtowanie świadomości społecznej celem zachowania dziedzictwa kulturowego Polski dla przyszłych pokoleń”, czemu ma służyć „wyznaczanie i upowszechnianie standardów ochrony oraz konserwacji zabytków". Dodajmy, że chodzi o dziedzictwo rozumiane szerzej niż zabytki materialne, a obejmujące również zjawiska niematerialne jako integralny i pełnoprawny wymiar kultury, wymagający swoistych technik i metod identyfikacji, dokumentacji czy ochrony.

W tym nurcie mieści się recenzowana publikacja. Składa się ona z dwóch książek: Dziedzictwo obok mnie - poradnik zarzadzania dziedzictwem $w$ gminach (256 s.; skrót - I) oraz DoM. Dziedzictwo obok mnie - inspiracje do działań lokalnych (100 s.; skrót - II; w wersji angielskiej o tytule układającym się w akronim HoME - Heritage of My Environment - Inspiration for local action). Powstały one 
w ramach projektu DoM - Dziedzictwo obok Mnie. Wartości dziedzictwa kulturowego dla społeczności lokalnych, który był realizowany przez NID wraz z Norweską Dyrekcją ds. Dziedzictwa Kulturowego (Riksantikvaren) (II, s. 10-25). Uczestniczyli w nim przedstawiciele trzech polskich gmin oraz pięciu gmin z Norwegii wraz z ekspertami z obu krajów, specjalizującymi się m.in. w takich zakresach zarządzania dziedzictwem, jak ochrona zabytków, rozwój regionalny, partycypacja społeczna, socjologia (I, s. 6). Program realizowano w formie objazdów studyjnych, podczas których uczestnicy z obu partnerskich krajów dzielili się wiedzą i doświadczeniami na niwie zarządzania dziedzictwem czy gospodarowania dziedzictwem w taki sposób, by wspierać rozwój lokalny i zarazem zachowywać tradycję dla przyszłych generacji. Otrzymaliśmy ostatecznie dwutomowy poradnik wydany na wysokim poziomie estetycznym, będący unikatem w tym sensie, że na polskim rynku brakowało do tej pory publikacji przeznaczonej dla samorządów, liderów i organizacji samorządowych, która w tak kompleksowy, klarowny i przystępny, a zarazem rzeczowy sposób omawiałaby „komplementarnie kwestie ochrony zabytków i opieki nad nimi oraz zagadnienia dotyczące lokalnego planowania zrównoważonego rozwoju, które mogą stanowić źródło wiedzy dla samorządów gminnych” (I, s. 6). Tytułowe zarządzanie dziedzictwem zdefiniowano zaś ,jako planowany proces ochrony i wykorzystania potencjału dziedzictwa w rozwoju gospodarczym i społecznym gminy" (I, s. 6).

Pierwszy z tomów składa się z trzech części, poprzedzonych wprowadzeniem, w którym zajęto się wyjaśnieniem pojęcia dziedzictwa kulturowego oraz jego interferencji z innymi terminami, jak też wyłożeniem motywacji przemawiającej za tym, że zarządzanie dziedzictwem przynosi wymierne korzyści gminie, włącznie z łagodzeniem problemów społecznych, zwłaszcza gdy do gospodarowania nim zaprosi się także interesariuszy i depozytariuszy dziedzictwa. Pierwsza część, zatytułowana Rozpoznawanie zasobu i tworzenie bazy wiedzy o lokalnym dziedzictwie (I, s. 18-55), poświęcona jest zagadnieniu identyfikacji dziedzictwa oraz jego wartości (społecznych i ekonomicznych) na poziomie lokalnym, stanu zachowania i zagrożeń dla tych zjawisk kultury. W postaci kolejnych pytań i odpowiedzi oraz objaśnień istotnych treści, popartych egzemplifikacjami, wykresami czy fotografiami, przybliżono krok po kroku zasady budowania bazy informacyjnej pod kątem procesu zarządzania dziedzictwem.

W części drugiej, zatytułowanej Rozwój lokalny - potencjat dziedzictwa kulturowego (I, s. 65-79), autorzy płynnie przeszli do następnego etapu zarządzania dziedzictwem, jakim jest ,rozpoznanie potencjału i wpływu dziedzictwa na procesy rozwojowe w gminie” (I, s. 57). Dlatego w dalszych partiach książki skupili się na analizie społeczno-gospodarczego potencjału dziedzictwa, z czym wiążą się m.in.: umiejscowienie dziedzictwa w strukturze procesów rozwoju lokalnego, zacieśnianie współpracy gmin z interesariuszami oraz korzystanie z metod pozwalających zidentyfikować bariery i czynniki rozwoju związane z lokalnym dziedzictwem. Praktyczny charakter publikacji obrazować może tytuł jednego z paragrafów: „Bariera rozwojowa może stać się także atutem...” (I, s. 78), co poparto przykładem włoskiej sieci Citaslow. Takie ujęcie przekonuje o szerokim, międzynarodowym kontekście, w jakim przedstawiono polskie dziedzictwo, połączonym z pozytywnym nastawieniem do rozwiązywania nawet najtrudniejszych problemów. 
Część trzecia, najobszerniejsza, Planowanie i wdrażanie zarządzania dziedzictwem - metody i narzędzia (I, s. 80-217), przybliża narzędzia projektowania i stosowania działań, które - pod warunkiem konsekwentnego i prawidłowego wykorzystania - uruchamiają potencjał dziedzictwa lokalnego, stymulują rozwój gminy przy jednoczesnym zachowaniu tego dziedzictwa. Rozpoczęto od prezentacji narzędzi prawnych, jakimi są m.in. ustawy, Karty (od Weneckiej z 1964 roku po Krakowską z 2000) czy rekomendacje UNESCO, a także relacji zarządzania dziedzictwem do innych płaszczyzn zarządzania $\mathrm{w}$ gminie, takich jak np. plan zagospodarowania przestrzennego, gminne ewidencje zabytków, programy opieki nad zabytkami, zasady wywłaszczania nieruchomości zabytkowej czy prawo jej pierwokupu. Następnie autorzy pochylili się nad omówieniem zagadnień przeciwdziałania najczęściej występującym zagrożeniom dla dziedzictwa, swoje propozycje popierając przekonującymi przykładami. Pokazali, że pierwszoplanowym środkiem w tym zakresie jest znalezienie "dla zabytku nowej funkcji, szanującej autentyzm i integralność" (I, s. 119-148). Jako kluczowy element słusznie wskazali tworzenie strategii zarządzania dziedzictwem, która zasadza się na dobrze zaprogramowanym rozwoju i której poświęcono proporcjonalnie dużo miejsca, dogłębnie referując, strukturując i egzemplifikując kolejne etapy tego istotnego procesu.

W dalszej części czytelnik zetknie się z prezentacją narzędzi stymulujących przedsiębiorczość lokalną i gospodarkę $\mathrm{w}$ aspekcie zarządzania dziedzictwem (I, s. 149-163). Zapozna się też z mechanizmami i metodami partycypacji społecznej (I, s. 164-179), gdyż ideą autorów jest uświadomienie lokalnym władzom, że efektywność zarządzania dziedzictwem rośnie wprost proporcjonalnie do udziału w tych procesach społeczności i liderów. Naprzeciw mechanizmom partycypacji wychodzi następny podrozdział, skrótowo omawiający metody badań społecznych, jakie mogą posłużyć społecznej diagnozie zasobów dziedzictwa lokalnego, rozpoznaniu postaw mieszkańców wobec tego dziedzictwa, ewaluacji dokumentów strategicznych itd. (I, s. 180-185). Za bardzo inspirujące i porządkujące wiedzę można też uznać partie poradnika poświęcone narzędziom upowszechniania wiedzy o dziedzictwie i aktywizującym społeczność (I, s. 186-204) - chodzi o pole edukacji, turystyki, promocji gminy i tworzenie marki miejsca. Kończąc, wspomniano o najważniejszych funduszach i programach pomocowych oraz o podstawowych wymogach podczas ubiegania się o wsparcie finansowe (I, s. 205-213). Przypomnijmy - do każdego z zagadnień dodano wiele trafnych tzw. dobrych przykładów, szereg cennych porad eksperckich, wskazano literaturę dla chcących pogłębiać wiedzę.

Poradnik zamyka aneks pt. Załączniki, do którego wybrano następujące materiały: Określanie wartości dóbr kulturowych światowego dziedzictwa UNESCO; Ochrona dziedzictwa niematerialnego: lista krajowa i kryteria wpisu; Wykaz praw i obowiązków gmin dotyczących dziedzictwa; Przykładowy kwestionariusz wywiadu dotyczący postaw mieszkańców wobec dziedzictwa. Następnie zapoznajemy się z listą autorów wydawnictwa oraz zakresami ich prac. Warto te osoby wymienić, gdyż wykonały rzetelnie swoją pracę, która dała harmonijny całościowy rezultat. To: A. Chabeira, A. Fortuna-Marek, B. Kazior, A. Kozioł, P. Legutko-Kobus, I. Liżewska, 
B. Markowska, M. Marciniak, P. Nowak, B. Skaldawski. Na tym jednakże poradnik się nie kończy - przechodzimy do jego integralnego elementu, czyli tomu drugiego.

DoM. Dziedzictwo obok mnie - inspiracje do działań lokalnych dokumentuje dobre praktyki zarządzania dziedzictwem w pięciu gminach Norwegii (Eid, Vågsøy, Øygarden, Fjell i Sund) i trzech Polski (Węgorzewo, Narol i Horyniec-Zdrój). Prezentację postaw, problemów, systemowych i zindywidualizowanych rozwiązań zaprezentowano w kolejnych zakresach. Są one następujące: znaczenie dziedzictwa dla społeczności lokalnych i rozwoju gmin oraz działania gmin na rzecz dziedzictwa kulturowego, gdzie pomieszczono kolejno opisy doświadczeń pięciu gmin biorących udział w projekcie. Najsilniej przekonujące i inspirujące mogą okazać się rezultaty wyjazdów studyjnych opisane w poradniku jako studia przypadków (II, s. 44100). Dziewiętnaście różnorodnych typów lokalnego dziedzictwa polskiego i norweskiego (od muzeum, przez obiekty zabytkowe i krajobraz kulturowy, po zjawiska dziedzictwa niematerialnego) posłużyło do zaprezentowania na przykładach narzędzi i wyników gminnego zarządzania dziedzictwem. Ujęto je w celnie zaprojektowane rozdziały, obrazujące kluczowe problemy: społeczne zaangażowanie na rzecz lokalnego dziedzictwa kulturowego; działalność gospodarcza w obiekcie zabytkowym; dziedzictwo niematerialne w lokalnych społecznościach; zaangażowanie muzeów na rzecz lokalnego dziedzictwa kulturowego; dziedzictwo kulturowe w lokalnych projektach rewitalizacyjnych oraz nowe funkcje zabytków.

Podsumowując, warto zwrócić uwagę na kilka atutów omawianego poradnika. Po pierwsze, mimo że w projekt DoM zaangażowani byli przedstawiciele samorządów gmin wiejskich i miejsko-wiejskich, to jednak zagadnienia ujęte w publikacjach mogą okazać się przydatne także w pracy władz lokalnych większych miejscowości. Po drugie, całość podporządkowana jest konsekwentnie jednej idei, że samorząd każdej gminy zdolny jest do efektywnego zarządzania dziedzictwem kulturowym, co z kolei może na wielu płaszczyznach przełożyć się na rozwój gminy. Po trzecie, autorzy udowodnili, że w przystępny sposób można mówić o aspektach praktycznych zagadnień skomplikowanych i wielopłaszczyznowych, jakimi są: skuteczne planowanie, programowanie i wdrażanie ochrony dziedzictwa oraz efektywne wykorzystanie jego elementów w rozwoju ekonomicznym i społecznym regionu. Może ich wiara i wysiłek przełożą się na kolejne dobre praktyki w polskich gminach, wioskach, miastach i na harmonijny wzrost świadomości władz samorządowych oraz depozytariuszy dziedzictwa.

\section{Bibliografia i netografia}

Narodowy Instytut Dziedzictwa, http://www.nid.pl/pl/ [odczyt: 16.06.2017].

Rozgryźć dziedzictwo. Podręcznik dobrych praktyk upowszechniania dziedzictwa i edukacji o dziedzictwie kulturowym, tekst K. Zarzycka, Narodowy Instytut Dziedzictwa, Warszawa 2016.

Zarzadzanie światowym dziedzictwem kulturowym, w serii: Poradnik światowego dziedzictwa, polskie thumaczenie tomu wydanego przez UNESCO (Paryż 2013), redakcja polskiej wersji językowej K. Piotrowska, D. Lipska, Narodowy Instytut Dziedzictwa, Warszawa 2015. 
Niematerialne dziedzictwo kulturowe, oprac. A. Marconi-Betka, K. Sadowska-Mazur, J. Włodarczyk, Narodowy Instytut Dziedzictwa, Warszawa [b.r.w.].

Heritage of My Environment - Inspiration for local action, Editorial team: A. Chabiera, N. Dahl-Poppe, I. Holm, A. Kozioł, B. Skaldawski, O.Ch. Tollersrud, Narodowy Instytut Dziedzictwa, Warszawa [2016].

Społeczno-gospodarcze oddziaływanie dziedzictwa kulturowego. Raport z badań społecznych, Zespół autorski A. Kozioł, M. Trelka, P. Florjanowicz, Narodowy Instytut Dziedzictwa, Warszawa 2013.

Niematerialne dziedzictwo kulturowe w Polsce i jego ochrona, t. 1, Niematerialne dziedzictwo kulturowe: źródta-wartości - ochrona, J. Adamowski, K. Smyk (red.), Narodowy Instytut Dziedzictwa, Lublin-Warszawa 2013, do pobrania, http://kulturaludowa.pl/aktualnosci/niematerialne-dziedzictwo-kulturowe-zrodla-wartosci-ochrona/ [odczyt: 3.05.2017].

Niematerialne dziedzictwo kulturowe w Polsce i jego ochrona, t. 2, Niematerialne dziedzictwo kulturowe: zakresy - identyfikacja - zagrożenia, J. Adamowski, K. Smyk (red.), Narodowy Instytut Dziedzictwa, Lublin-Warszawa 2015, do pobrania, http://kulturaludowa.pl/aktualnosci/ niematerialne-dziedzictwo-kulturowe-zakresy-identyfikacja-zagrozenia/ [odczyt: 3.05.2017].

Niematerialne dziedzictwo kulturowe w Polsce i jego ochrona, t. 3, Narracja, obyczaj, wiedza... O zachowaniu niematerialnego dziedzictwa kulturowego, A. Przybyła-Dumin (red.), Muzeum „Górnośląski Park Etnograficzny w Chorzowie”, Narodowy Instytut Dziedzictwa, ChorzówLublin-Warszawa 2016. 